\title{
MONEY SUPPLY AND EXPORTS: A GREATER MEKONG SUBREGION PERSPECTIVE
}

\author{
David Y. Chen, North Carolina A\&T State University, U.S.A. \\ Huan Li, North Carolina A\&T State University, U.S.A.
}

dx.doi.org/10.18374/JABE-20-1.2

\begin{abstract}
This paper investigates causational effect between domestic money supply and exports in the Greater Mekong Subregion (GMS) when trade is extended beyond the subregion. Following the export-led economic growth and gravity trade approach, we adopt a simple Dynamic Stochastic General Equilibrium representation with two rational expectation components, a Taylor rule for interest rate, a built in inflation target for six GMS and nine representative major trade countries to examine effect of domestic consumption expenditures and China's exchange rate regime on country-specific money supply and exports. We find lagged changes in national exports have near zero effect on contemporaneous change in national money supply, but changes in lagged money supply have very significant effect on changes in contemporaneous exports. Cambodia, Laos, and Vietnam seem to react similarly with largest positive money changes from domestic consumption expenditures shock and largest negative money change from change in exports. Myanmar has opposite effect than these three countries. Only Thailand has magnitude in causation like the industrialized nations.
\end{abstract}

Keywords: Greater Mekong Subregion, Money Supply, Exports, DSGE Model 